\title{
A rendőrök kiválasztásának hatékonysága
}

\section{MOGYORÓDI Gergely}

\begin{abstract}
A publikáció a bemeneti követelmények szerepével mint a rendőrség hatékonyságának egyik aspektusával foglalkozik. A vonatkozó szakanyagokon keresztül feltárja és elemzi az összefüggéseket. A cikk emellett kitér a hazai rendszerben jelenleg alkalmazott módszerek hatékonyságának aggályaira, valamint megoldási javaslatként a külföldi rendörségek által alkalmazott eljárásokra.
\end{abstract}

Kulcsszavak: rendőr, kiválasztás, teljesítmény, hatékonyság

A rendőrség és a hatékonyság a köznapi értelemben, illetve a szakma gyakorlatában általában összemosódik a különböző statisztikai adatokkal, például a regisztrált bû́ncselekmények számával vagy a felderítési mutatókkal.

A rendészeti szakirodalomban tömegével találunk tanulmányokat a hatékonyságról, kisebb számban pedig olyan jellegűeket, amelyek a kiválasztás és az alkalmassági vizsgálatok szerepét mint a teljesítménynövelés egyik lehetséges irányát hangsúlyozzák.

Csatai $^{2}$ a magyar rendőrök kiválasztásáról a következőket írta: „eddigi tapasztalataim alapján úgy ítélem meg, hogy a jelenlegi alkalmassági rendszerünk - elismerve a több mint ötvenéves egészségi alkalmassági rendszer nemes hagyományait, valamint mintegy 15-20 éves pszichológiai és fizikai alkalmassági rendszer "szárnypróbálgatásait « - ma már nem segíti kellő hatékonysággal a korszerű rendőri követelményeknek megfelelő emberi erőforrás kiválasztását. A megfelelő szemlélet és gyakorlat hiányosságaiból adódó paradoxon, hogy a kiválasztás szabályozottnak, részletesnek, szakmailag megalapozottnak mondható, mégis, a kiválasztottak egy része rövid idő után alulteljesít, beilleszkedési zavarokkal küszködik, pszichoszomatikus betegségei lesznek."

Az előbbi gondolatok alapján feltételezhető, hogy a rendőrség kiválasztási rendszere nem kellően hatékony.

A kiválasztás, ezen belül az alkalmasságvizsgálatok célja a legmegfelelőbb ember megtalálása egy adott beosztásra, amellyel növekszik a szervezet hatékonysága.

MOGYORÓDI Gergely r. őrnagy, mb. osztályvezető-helyettes, Nemzetközi Bűnügyi Együttműködési Központ SIRENE Iroda, PhD-hallgató, NKE Rendészettudományi Doktori Iskola

Gergely MOGYORÓDI police major, deputy head, International Law Enforcement Center SIRENE Bureau, PhD student, National University of Public Service, Doctoral School of Law Enforcement Science

orcid.org/0000-0002-1598-305X, mogyorodig@nebek.police.hu

2 Csatai (2010) 97. 
Az alkalmasságvizsgálat eredménye és a munkahelyi teljesítmény között pozitív kapcsolat van, a leendő munkavállalók munkahelyi magatartása a vizsgálatokkal előrejelezhető, ami növelheti a bevált egyének számát.

A hatékonyság és az egyéni teljesítmény tehát egymástól elkülönülő, de szoros kölcsönhatásban álló fogalmak.

A szervezet hatékonyságát a célok elérésén, az érdekcsoportok elégedettségén, a belső folyamatokon és a források megszerzésén keresztül mérhetjük, azonban a teljesítményt végső soron a szervezetben dolgozó egyének kompetenciái határozzák meg.

Míg a versenyszféra szervezeteinek nyereséget kell termelnie, addig az állami szférára ez az állítás nem igaz, azonban a hatékonyság az utóbbi esetében is alapkérdés.

A civil szektor a kiválasztási stratégiát a jelentkezők kompetenciáinak vizsgálatára helyezi, amely magában foglalja a motiváció, a tudás, a személyiség és a különböző képességek ellenőrzését, amely alkalmasságvizsgáló módszerekben a magyar közszolgálat kisebb mértékben érdekelt. ${ }^{3}$

Csatai, valamint Klein és Klein álláspontjait alapul véve a rendőrség kiválasztási rendszeréről feltételezhetjük, hogy nem kellően effektív, illetve az alkalmasságvizsgáló módszerei idejétmúltak.

A fentieket alapul véve, meglátásom szerint a következő kérdésekre érdemes választ keresni: melyek a magyar rendőrök kiválasztásának hatékonyságát gátló tényezők, melyek azok a modern alkalmasságvizsgáló módszerek, amelyeket más külföldi rendőrségek eljárásában megtalálhatók.

A tanulmány fenti kérdéseket tárgyalva először a kiválasztást gátló tényezőkkel, ezt követően az angolszász típusú rendőrségek által használt modern alkalmasságvizsgáló módszerekkel foglalkozik.

\section{A hazai kiválasztási rendszer hatékonyságát gátló tényezők}

A modern értelemben vett rendőrrel szemben már a kezdeti időkben is elvárás volt az egészségügyi alkalmasság, míg a fizikai és a pszichikai vizsgálatok váltak az eljárás részévé.

A személyi feltételek, így az életkor, az állampolgárság vagy az erkölcsi értékek (például a büntetlen előélet) kisebb változásokkal szinte ugyanazok voltak, míg a képesítés vonatkozásában az elvárások konstans fejlődésen mentek keresztül.

A rendszerváltozást követően, a Team Consult gazdasági társaság a magyar rendőrséget átvilágította, amely után a rendőri tisztviselőkkel szemben az alábbi elvárásokat fogalmazta meg: ${ }^{4}$

- „autonóm lény, aki viseli a felelősséget;

- kommunikációra alkalmas;

- konfliktusokat és stresszt vállaló;

Klein-Klein (2012) 53., 88., 138., 143-144.

Finszter (2013) 128-129. 
- együttmúködésre nyitott;

- döntésképes;

- járatos az új technikák alkalmazásában;

- megújulásra kész;

- nagy munkabírású;

- világnyelvek ismerője."

A fenti szellemi elvárásokon túl a jelenlegi kiválasztási rendszer jóval összetettebb követelményeket fogalmaz meg a jelentkezőkkel szemben. ${ }^{5}$

Ezekkel a követelményekkel kapcsolatban Csatai ${ }^{6}$ a következő kritikát fogalmazta meg: „[A] rendőrség csak akkor képes megfelelni, ha a szolgálatellátás minősége javul, a szolgálati teljesítmény növekszik. E minőségi és mennyiségi követelmények alapvető elemei közös tőről, azaz a gazdasági és humán erőforrásokkal való helyes gazdálkodás tényezőiből fakadnak, ezek egymást átfedik és nem választhatók el egymástól. A humánerőforrás-gazdálkodás alapja a rendőr-alkalmassági követelményrendszer múködése-múködtetése, amely - a mai fogalmaink szerint - öt követelménycsoportba (személyi, képesítési, fizikai, pszichikai, egészségügyi) sorolható, de a csoportok szakmai szempontrendszere egyeztett, közös szemléleti alapra és együttes gyakorlati tennivalókra kell hogy helyeződjön, mivel az alkalmassági felmérés, illetve elbírálás rendkívül összetett kérdés, így egyik szakterület dominanciája sem engedhető meg."

A dominancia a vizsgálatok sorrendjében jelentkezik. Példaértékű a fizikai tesztek szűrőereje, amit véleményem szerint jól szemléltetnek a Nemzeti Közszolgálati Egyetem Rendészettudományi Karának alábbi statisztikai adatai. ${ }^{7}$

5 A szolgálati viszony létesítésének feltételeit jelenleg a 2015. évi XLII. törvény (továbbiakban: Hszt.) 33. szakasz (1) bekezdése határozza meg, eszerint:

„Szolgálati viszony azzal az önként jelentkező, cselekvőképes, állandó belföldi lakóhellyel rendelkező magyar állampolgárral létesíthető,

a) aki a tizennyolcadik életévét betöltötte, és életkora - az e törvényben meghatározott kivételekkel - a hivatásos szolgálat rá irányadó felső korhatáránál legalább tíz évvel kevesebb,

b) aki rendelkezik a tervezett szolgálati beosztás besorolási osztálya szerint meghatározott iskolai végzettséggel és szolgálati viszonyra vonatkozó szabályban a szolgálati viszony létesítésének feltételeként meghatározott szakképzettséggel,

c) aki a hivatásos szolgálatra és a tervezett szolgálati beosztására egészségi, pszichikai és fizikai szempontból alkalmas." Az alkalmassági vizsgálatokat részletesen az 57/2009. (X. 30.) IRM-ÖM-PTNM együttes szabályozza. A jogszabály 3. szakaszának (1) bekezdése szerint „a szolgálati, munkaköri követelmények érvényre juttatása érdekében a személyi állomány tagja hivatásos szolgálatra való alkalmasságát, egészségi, pszichikai és fizikai állapotát a szolgálati viszony [...] létesítését megelőzően és annak fennállása alatt rendszeresen vizsgálni és véleményezni kell (a továbbiakban együtt: alkalmassági vizsgálat). A rendészeti oktatási intézményekbe jelentkezők számára előírt követelményeknek való megfelelés megállapítása érdekében is vizsgálni kell az alkalmasságot."

Csatai (2010) 84.

7 Az adatokat a Nemzeti Közszolgáti Egyetem Rendészettudományi Karának Tanulmányi Osztálya bocsájtotta rendelkezésre. A számok valamennyi rendészeti szakirányra jelentkezett hallgatóra vonatkoznak, külön szakirányokra bontva információ nem állt rendelkezésre, korábbi adatok nem voltak elérhetők. 


\begin{tabular}{|c|c|c|}
\hline \multicolumn{3}{|c|}{ 2013. felvételi eljárás a datai } \\
\hline Behívottak & \multicolumn{2}{|l|}{ Fizikai } \\
\hline \multirow{3}{*}{1526} & nem jelent meg & 257 \\
\hline & alkalmatlan & 486 \\
\hline & alkalmas & 783 \\
\hline \multicolumn{3}{|c|}{ 2014. felvételi eljárás adatai } \\
\hline Behívottak & \multicolumn{2}{|l|}{ Fizikai } \\
\hline \multirow{3}{*}{1783} & nem jelent meg & 347 \\
\hline & alkalmatlan & 558 \\
\hline & alkalmas & 878 \\
\hline \multicolumn{3}{|c|}{ 2015. felvételi eljárás adatai } \\
\hline Behívottak & \multicolumn{2}{|l|}{ Fizikai } \\
\hline \multirow{3}{*}{1570} & nem jelent meg & 287 \\
\hline & alkalmatlan & 443 \\
\hline & alkalmas & 840 \\
\hline \multicolumn{3}{|c|}{ 2016. felvételi eljárás adatai } \\
\hline Behívottak & \multicolumn{2}{|l|}{ Fizikai } \\
\hline \multirow{3}{*}{1452} & \begin{tabular}{|l|} 
nem jelent meg \\
\end{tabular} & 485 \\
\hline & alkalmatlan & 299 \\
\hline & alkalmas & 668 \\
\hline
\end{tabular}

A fenti adatokból látható, hogy általában a jelentkezők nagy része el se megy, míg a megjelent személyek harmada eredménytelen.

Az erőnléti teszt első helyen történő szerepeltetése kizárólag költséghatékonysági szempontokra vezethető vissza. Ez a szakasz jóval kevesebb költségvonzattal jár, mint a soron következő egészségügyi vagy pszichológiai vizsgálat.

Meglátásom szerint a költséghatékony viszonyulás képezi a legnagyobb akadályt a megfelelő humán erőforrás kiválasztásában.

Szem előtt tartva, hogy a rendőrség a fizikai erőszak legitim monopóliumával rendelkező társadalmi szerv, a technikai és taktikai fejlődésnek köszönhetően az egyéni erő szerepe folyamatosan csökken. Emellett a szolgálati ágak jelentős része szellemi, adminisztratív tevékenység, így az egyének teljesítményének nem az erőnlét az elsődleges feltétele.

Különösebb tudományos elemzés nélkül is belátható, hogy az alkalmassági kritériumok közül a fizikum a legkönnyebben és a leggyorsabb fejleszthető terület. Ennek megfelelően, az erőnléti állapotnak nem a kiválasztásban kellene domináns szerepet kapnia, hanem a szolgálati igényekhez mérten inkább az oktatás során. Az önképzésére való igény kialakítása, valamint a kimunkált állapot fenntartására való felkészítés a rendőrképzés feladata, a kiválasztással ebben az esetben „nem vásárolhatunk kész

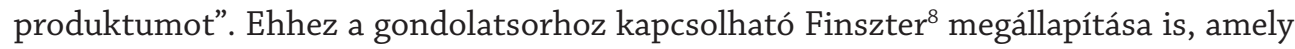
szerint „minden reform egyik kulcsprogramja a szakoktatás, ahol a felsorolt erények megszerezhetők, vagy annak lehetősége a jelölt számára megteremthető”.

\footnotetext{
$8 \quad$ Finszter (2013) 129.
} 
Összefoglalva, az eljárás költséghatékonyságának biztosítása miatt, túlzott mértékủ szellemi tőkét és vélhetően szolgálat ellátására alkalmas egyént vesztünk el az erőnléti vizsgálatok során.

Csatai gondolataival egyetértve, a lépcsőzetes folyamat helyett inkább az együttes elbírálás felé kellene a változásokat elmozdítani.

\section{Modern alkalmasságvizsgáló módszerek (a külföldi rendörségek kiválasztásában)}

Ebben a részben az általam tanulmányozott külföldi rendszerekben használt modern alkalmasságvizsgáló eljárásokról írok. Egyes módszerek alkalmazása pontosan azokat a költséghatékonysági szempontokat követi, mint hazánkban az erőnléti vizsgálat.

A példákat az angolszász területről hozom, amelyek természetesen a magyar közszolgálati rendszerrel nem hasonlíthatók össze, a kettő között nem lehet párhuzamot vonni, azonban a rendszerekben találhatóak olyan elemek (például az online önismereti kérdőívek vagy az előszűrő tesztek), amik megítélésem szerint pozitívan hathatnak a kiválasztás hatékonyságára.

A magyar rendőrök kiválasztása során a kompetenciák a pszichológiai alkalmassági vizsgálatok alatt csak részszerepet kapnak.

$\mathrm{Az}$ angolszász kiválasztási rendszerben, a modern alkalmasságvizsgáló technikák középpontjában álló kompetenciákra fókuszálnak, és mivel a hangsúly erre helyeződik, a vizsgálatok sorrendje sem az erőnlét feltérképezésével, hanem pszichikum kiértékelésével kezdődik.

A legtöbb esetben az eljárás nem egy belső fejlesztés eredménye, hanem a minőség biztosítására külső gazdasági társasággal szerződnek. ${ }^{9}$

A kiszervezés lényege, hogy „a már meglévő, korábban a vállalatban a szervezeten belül ellátott feladatokat, tevékenységeket jogilag elkülönült külső szolgáltatóra bízzák". ${ }^{10}$ Humán területen, a kiválasztás egyik leggyakrabban kiszervezett feladatkör, amely alkalmazásának egyik előnye az időmegtakarítás, a szakértelem biztosítása, valamint a költséghatékonyság növelése. ${ }^{11}$

A technikák közül az önszelekciót, az online felületen történő, előszelekcióra használt teszteket, valamint az értékelő központok alkalmazását szeretném kiemelni. ${ }^{12}$

$\mathrm{Az}$ önszelekció lényege, hogy az álláshirdető által rendelkezésre bocsájtott információk alapján az érdeklődő el tudja dönteni, hogy az ajánlatban foglaltak számára reálisan elérhetők-e. A módszer a jelentkezőt teljeskörűen tájékoztatja az elvárásokról

\footnotetext{
Lásd Észak-Írországban a kiválasztás meghatározott szakaszait a Deloitte végzi (Guidance for Applicants).

Karoliny-Poór (2013) 111.

1 Karoliny-Poór (2013) 115.

12 Jelen publikációnak nem célja, hogy a felsorolt országok vonatkozásában a felvételi eljárás menetét ismertesse, mert ezek korábban publikálásra kerültek, lásd (Mogyoródi, 2016a) és (Mogyoródi, 2016b)
} 
és a munkakörülményekről, emellett hatékony és költségtakarékos is. ${ }^{13}$ Alkalmazására példát Anglia és Wales rendőrségénél láthatunk. ${ }^{14}$

Az online alkalmasságvizsgáló rendszer egy olyan automatizált módszer, amelyek során a beválással összefüggő standard kérdőíveket használnak, célja a társaság számára releváns információk beszerzése. A háttéradatok begyűjtésével a megfelelő végzettség vagy tudás hiánya kiszűrhető, az előszelekció pedig az objektív alkalmasságvizsgáló eszközökkel történik.

Ezeknek az eszközöknek a hatékonysága az objektív értékelési rendszerben és a nagyobb feldolgozó képességben rejlik. ${ }^{15}$

A magyar rendőrség kiválasztási eljárásában az objektív értékelés, valamint a nagy feldolgozó képesség egyaránt kívánalom (például az egyes képzésekre jellemző túljelentkezések kezelésére), ami a módszer alkalmazásának bevezetése mellett szól.

Klein és Klein ${ }^{16}$ a „vezető-utánpótlás kiválasztásának leghatékonyabb módszereként” beszél az úgynevezett értékelő központokról (Assessment Centre), amely „eljárás: olyan módszer-együttes, ahol több kompetencia alapján, több szimulációs gyakorlat (és többnyire más módszerek) segítségével, több értékelő, több jelöltet vizsgál egyszerre és az eredményeket integrálják".

Karoliny és Poór meghatározásában „olyan munkapróbák, szituációk sorozata, amelyek az adott vezetői szint, vagy egy-egy munkakör legfontosabb feladatait, szerepeit modellezik" ${ }^{17}$

Klein és Klein az értékelő központok előnyeként emelte ki, hogy nem „sưrítik össze a megismerés folyamatát”. Nem szorítja ki az alkalmassági vizsgálatok során használt módszereket, hanem „egy újabb lehetőség azokban az esetekben, amikor a szervezet hajlandó nagyobb erőfeszítésekre a pontosabb előrejelzés érdekében” ${ }^{18}$

Ilyen módszer alkalmazására láttunk példát Anglia és Wales rendőrsége vagy akár az északír rendőrség esetében is.

Az előbbi szerv értékelő központjaiban átlagosan a jelentkezők 8\%-a felel meg. ${ }^{19}$

A fentieket egybefoglalva, a modern alkalmasságvizsgáló módszerek fókuszpontjában az egyéni képességek vizsgálata áll. Az angolszász modellben is ezekre az eljárásokra helyezik a hangsúlyt, amelynek a végrehajtását szervezeten kívüli társaságoknak közvetítik ki.

A szakirodalmi ajánlások alapján bevezetésükkel nő az objektivitás, ezzel egyidejűleg növekszik a költséghatékonyság.

\footnotetext{
Klein-Klein (2012) 329.

Mogyoródi (2016a)

Klein-Klein (2012) 329., 332.

Klein-Klein (2012) 279.

Karoliny-Poór (2013) 266.

Klein-Klein (2012) 292.

Mogyoródi (2016a) 95.
} 


\section{Összefoglalás}

A bevezetésben írtakra visszautalva a tanulmány két kérdésre keresett választ. Az első a magyar rendőrség kiválasztási rendszerének hatékonyságát gátló tényezőre, a második pedig az alkalmazott módszerek korszerűségére vonatkozott.

A megállapításokat összefoglalva és Csatai gondolataival egyetértve, a kiválasztás hatékonyságát a vizsgálatok dominanciája, valamint az együttes értékelésének akadálya jellemzi, amely meglátásom szerint az eljárás költséghatékony múködésének biztosítására vezethető vissza.

A modern alkalmasságvizsgáló módszerek a kompetenciák vizsgálatában látják a lehetőséget, amelyek az angolszász típusú rendőrségek kiválasztási rendszerében meghonosodtak.

A közszolgálatok közti különbségek miatt az angolszászt a magyar rendszerrel nem lehet párhuzamba állítani, azonban a felsorakoztatott példák támpontként szolgálhatnak a magyar rendőrök kiválasztásának fejlesztéséhez.

A szakirodalmi ajánlások szerint ezekkel a módszerekkel növelhető a kiválasztás hatékonysága, ami pozitívan hat az egyéni teljesítményre.

\section{IRODALOMJEGYZÉK}

Csatai Tamás (2010): A rendőrré válás és a szolgálatellátás alatti pályaalkalmassági követelmények alakulása az 1800-as évek végétől napjainkig. Belügyi Szemle, 58. évf. 7-8. sz. 84-99.

Finszter Géza (2013): A rendészet elmélete és a rendészeti eszközrendszer. Budapest, Nemzeti Közszolgálati és Tankönyv Kiadó Zrt.

Karoliny Mártonné - Poór József (2013): Emberi erőforrás menedzsment kézikönyv. Budapest, Complex Kiadó Jogi és Üzleti Tartalomszolgáltató Kft.

Klein Balázs - Klein Sándor (2012): A szervezet lelke. Budapest, EDGE 2000 Kiadó.

Mogyoródi Gergely (2016a): Anglia és Wales hivatásos rendőri állományának kiválasztási eljárása és annak összevetése a hazai követelményekkel. Magyar Rendészet, 16. évf. 6. sz. 93-108.

Mogyoródi Gergely (2016b): Az An Garda Síochána (az ír rendőrség) képzési és állománykiválasztási rendszere. Magyar Rendészet, 16. évf. 5. sz. 123-138.

Nemzeti Közszolgálati Egyetem Rendészettudományi Kar Tanulmányi Osztálya által rendelkezésre bocsátott 2013-2016 felvételi alkalmassági vizsgálatok statisztikai adatai.

\section{Internetes forrás}

Guidance for Applicants. Forrás: www.joinpsni.co.uk/downloads/Guidance-for-Applicants.pdf (2017. 01. 04.)

\section{Jogforrások}

57/2009. (X. 30.) IRM-ÖM-PTNM együttes rendelet egyes rendvédelmi szervek hivatásos állományú tagjai egészségi, pszichikai és fizikai alkalmasságáról, közalkalmazottai és köztisztviselői munka- 
köri egészségi alkalmasságáról, a szolgálat-, illetve keresőképtelenség megállapításáról, valamint az egészségügyi alapellátásról.

2015. évi XLII. törvény a rendvédelmi feladatokat ellátó szervek hivatásos állományának szolgálati jogviszonyáról.

\section{ABSTRACT}

\section{The Role and Possibilities of Selection in the Effectiveness of the Police}

MOGYORÓDI Gergely

The paper presents the role of eligibility criteria as an aspect of effectiveness of the police. Through literature it reveals and analyses the connection between selection and effectiveness, besides it goes into details of concernment of Hungarian selection methods. The paper also instances the procedures of foreign police forces as a proposal for solution.

Keywords: police, selection, performance, effectiveness 